\title{
EVALUASI IMPLEMENTASI PROGRAM PAUD TERPADU DI TK NEGERI 1 PEMBINA SAMARINDA
}

\author{
Fachrul Rozie \\ Program Studi Pend. Guru PAUD, Fakultas Keguruan dan Ilmu Pendidikan, UNMUL; \\ fachrulroziepgpaud@gmail.com \\ Farny Sutriany Jafar \\ Program Studi Pend. Guru PAUD, Fakultas Keguruan dan Ilmu Pendidikan, UNMUL; \\ farny_sutriany@yahoo.co.id
}

\begin{abstract}
This evaluation study aims to determine the effectiveness of the implementation program for the integration of early childhood in the 1 Trustees State Kindergarten in 2017/2018. The evaluation study was chosen as a research method, using the CIPPO Model from Daniel Stufflebeam developed by Gilbbert Sax. This study uses multi techniques and instruments to collect data and analyze data using descriptive statistics and qualitative techniques. The results of the study show: (1) Component Context: TK 1 Country Pembina Samarinda has several legal documents of all implementations. Parental and community support has been shown well, so the perspective of managers who register for implementation shows that they are developing programs. (2) Input Components: student groups are relevant to age. The qualifications and number of teachers are relevant to the criteria. TK Negeri 1 Pembina Samarinda has very complete resources, but does not have natural resources. Financial reports show good results from resource financing. Planning the implementation of the program shows the relevance of the criteria. (3) Process Components: Implementation of reference for children's development milestones and BCCT concepts. There are some disabled children who cannot adapt to learning. In the evaluation refer to Permendikbud Number 137, 146, and 31 of 2014 and a milestone in the development of children. (4) Product Components: Reports on research results indicate school development and readiness. (5). Component of Results (outcome): The perspective of elementary school teachers shows that graduates of Samarinda State 1 Kindergarten Kindergarten have adapted in the learning process in grade 1 elementary school.
\end{abstract}

Keywords: integrated PAUD, program evaluation, early childhood 


\section{PENDAHULUAN}

Pendidikan anak usia dini adalah pendidikan dasar untuk kehidupan. Ini membuat pemerintah sadar bahwa penerapan pendidikan anak usia dini yang tepat akan membantu pemerintah dalam mempersiapkan generasi emas berikutnya pada tahun 2045.Fakta ini sesuai dengan fakta yang bersumber dari data BPS, bahwa sensus Indonesia ke depan (2012) Indonesia akan memperoleh bonus demografi yang besar. Kelompok umur anak 0 - 4 tahun adalah 22.678.702 dan kelompok umur 5 - 9 tahun adalah 23.253.480. Banyaknya bonus demografis untuk ruang lingkup anak usia dini perlu dipersiapkan sehingga mereka dapat membawa bangsa Indonesia menjadi generasi emas. Keberadaan spesimen PAUD membantu institusi PAUD lainnya untuk memberikan layanan yang berkualitas. Pemerintah Indonesia telah meluncurkan program spesimen PAUD sebagai "arah" untuk masing-masing daerah (Fasli Jalal, 2014).

Program PAUD terintegrasi adalah salah satu program yang diselenggarakan oleh pemerintah melalui kementerian pendidikan. Istilah yang paling akrab adalah Pilot Project of PAUD. Ini adalah latar belakang APK (Angka Partisipasi Kasar) menyelenggarakan dan berpartisipasi pada program PAUD masih menurun. Pemerintah meluncurkan program PAUD Terpadu di berbagai tingkatan di desa, kota, dan provinsi, bertujuan untuk meningkatkan kualitas dan layanan yang diselenggarakan oleh Direktorat Pengembangan Pendidikan Anak Usia Dini.

$$
\text { Berbagai konsep program PAUD }
$$
terintegrasi dijelaskan lebih lanjut dalam legalitas Implementasi Program Anak Usia Dini Terintegrasi yang berisi prinsip-prinsip implementasi Program Pendidikan Anak Usia Dini Terpadu, persyaratan untuk pelaksanaan Sekolah Lansia Terpadu, struktur lembaga PAUD Organisasi terpadu, program dan kegiatan pembelajaran, partisipasi masyarakat, dan pola pengembangan program PAUD Terpadu. Program Pendidikan Anak Usia Dini Terintegrasi adalah program layanan pendidikan anak usia dini yang menyelenggarakan lebih dari satu program PAUD (TK, KB, TPA, SPS) yang dalam pembinaan, pengorganisasian dan manajemen dilakukan secara terintegrasi atau terkoordinasi (Tedjawati, 2010).

Salah satu lembaga yang menjadi PAUD percontohan di Samarinda adalah TK Negeri Pembina 1 Samarinda. Keunggulan yang dimiliki adalah adanya penyelenggaraan program PAUD terpadu dan pelaksanaan pendidikan inklusif bagi anak usia dini. Menyadari kemajuan dan keunggulan di dalam TK Pembina 1 Samarinda ternyata tidak lepas dari hasil penilaian oleh pihak akreditasi yang telah mengevaluasi. Hasil evaluasi oleh tim akreditasi memberikan dampak terhadap TK Negeri Pembina 1 Samarinda yang menjadi percontohan. Banyak lembagalembaga di sekitar yang menimba ilmu dan 
pengalaman. Hal tersebut membuat TK Negeri Pembina 1 Samarinda untuk mampu menciptakan berbagai inovasi baru. Karena mempertahankan label percontohan lebih sulit daripada meraihnya.

Berdasarkan pemaparan tersebut, dapat diketahui bahwa belum pernah diadakan penelitian evaluatif secara akademis terhadap TK Negeri Pembina 1 Samarinda. Mengingat keunggulankeunggulan di atas peneliti merasa perlu diadakan evaluasi secara akademis. Sebagai salah satu bentuk program penelitian kepada stakeholder TK Negeri Pembina 1 Samarinda untuk mendapatkan gambaran secara holistik atas pencapaian yang telah di dapat dan dapat digunakan sebagai bahan keputusan terhadap penyelenggaraan program PAUD Terpadu.

Beberapa dasar untuk pelaksanaan program PAUD Terpadu adalah dasar dari kebijakan pemangku kepentingan yang dirangkum dalam dasar yuridis seperti Undang-Undang Nomor 20 Tahun 2003, Permendiknas Nomor 58 Tahun 2009, Permendikbud Nomor 137 Tahun Tentang Standar PAUD Nasional, Permendikbud Nomor 146 Tahun 2014 Tentang Kurikulum Anak Usia Dini dan Permendikbud Nomor 31 Tahun 2014 Tentang Kerjasama International PAUD yang Dipandu Pemerintah.

Beberapa dasar pelaksanaan Program Pendidikan Anak Usia Dini Terpadu, menunjukkan kepatuhan dengan 8 standar nasional pendidikan yang tercantum dalam PP RI No. 13 tahun 2015 meliputi (Soegeng Santoso, 2011):

1. Lulusan Standar Kompetensi

2. Standar Isi

3. Standar Proses

4. Standar Pendidik / Guru Pendidikan

5. Standar Sarana - Prasarana

6. Standar Pengelolaan

7. Standar Pembiayaan

8. Standar Penilaian

Evaluasi adalah proses menentukan apakah tujuan filosofi, dan tujuan program telah dipenuhi. Interprestasi dan keputusan dibuat berdasarkan informasi yang dikumpulkan. Penilaian dan evaluasi terkait erat dan dapat terjadi secara bersamaan (Hilda Jackman, 2012). Alkin (1981) berargumen "evaluasi adalah proses memperoleh bidang keputusan yang menjadi perhatian, memilih informasi yang sesuai untuk melaporkan data ringkasan yang berguna bagi pengambil keputusan dalam memilih di antara alternatif" (Djudju Sudjana, 2008). Dalam sebuah program yang tengah berjalan, maka kebutuhan informasi akan kondisi program merupakan suatu hal yang sangat diperlukan bagi organisasi atau lembaga yang menggagasnya. Kebutuhan akan data atau informasi dapat diketahui melalui evaluasi. Program adalah kegiatan atau aktivitas yang dirancang untuk melaksanakan kebijakan dan dilaksanakan untuk waktu yang tidak terbatas (Wirawan,2012). Hal senada dari Suharsimi Arikunto (2010) mendefinisikan program dalam arti sempit dan luas. 
Program dalam arti sempit adalah suatu unit atau kesatuan kegiatan yang merupakan realisasi atau implementasi dari kebijakan. Sedangkan, dalam arti luas program merupakan sebuah sistem, yaitu rangkaian kegiatan yang dilakukan bukan hanya satu kali tapi berkesinambungan. Dalam ilmu evaluasi program pendidikan, terdapat banyak model yang digunakan untuk mengevaluasi suatu program. Meskipun antara satu model dengan yang lainnya berbeda, namun maksudnya sama yaitu untuk melakukan kegiatan pengumpulan data atau informasi yang berkenaan dengan objek yang dievaluasi, yang tujuannya menyediakan bahan bagi pengambil keputusan dalam menentukan tindak lanjut suatu program.

Khususnya dalam penelitian ini peneliti memilih model penelitian evaluasi dengan model CIPPO yang terdiri dari komponen konteks, input, proses, produk dan outcomes yang dikembangkan oleh Stufflebeam dan telah disempurnakan oleh Gilbert Sax dengan menambahkan satu komponen hasil (Stufflebeam, 2000). Salah satu model yang digunakan dalam melakukan evaluasi di bidang pendidikan. Konteks untuk sistem pendidikan tujuan evaluasi konteks adalah untuk menentukan konteks kelembagaan, mengidentifikasi populasi sasaran dan menilai kebutuhannya, mengidentifikasi peluang untuk memenuhi kebutuhan, dan menilai apakah solusi yang diusulkan (umumnya dalam bentuk tujuan) responsif terhadap kebutuhan yang dinilai.
Masukan adalah untuk mengetahui tingkat kesiapan, baik sumber daya maupun instrumen manajemen.

$$
\text { Pemilihan model evaluasi CIPPO }
$$
didasarkan pada implementasi Program Pendidikan Anak Usia Dini Terintegrasi (Terpadu) di TK Negeri Pembina 1 Samarinda adalah kategori program layanan mengingat produk atau hasil dari program ini adalah melayani target, target nya adalah siswa dalam rangka untuk memiliki kesiapan bersekolah sebelum memasuki jenjang pendidikan selanjutnya. Selain itu, untuk mengetahui hasil atau dampak pada kualitas kemampuan lulusan yang melanjutkan pendidikan di sekolah dasar.

Dengan demikian, berdasarkan beberapa fondasi pelaksanaan Program Anak Usia Dini Terpadu dan Model Evaluasi Program yang dipilih adalah CIPPO yang tepat untuk melakukan kegiatan evaluatif dari evaluator eksternal di TK Negeri Pembina 1 Samarinda.

\section{METODE PENELITIAN}

Tujuan dari penelitian ini adalah untuk mengetahui landasan pelaksanaan PAUD terintegrasi, dukungan sosial orang tua dan masyarakat, perspektif manajemen tentang implementasi, manajemen anak dan guru, ketersediaan sarana dan prasarana, manajemen pembiayaan, perencanaan program pembelajaran, implementasi dan penilaian program pembelajaran, anakanak, kesiapan anak untuk memasuki pendidikan lanjutan di sekolah dasar, dan 
persepsi pemangku kepentingan di sekolah dasar terhadap lulusan TK Negeri 1 Pembina Samarinda terkait dengan kemampuan akademik dan non akademik. Penelitian ini adalah penelitian evaluatif dengan menggunakan pendekatan kualitatif. Untuk tujuan penelitian, peneliti menggunakan beberapa teknik pengumpulan data seperti observasi, wawancara, dokumentasi, dan kuesioner. Penelitian dilakukan dari April hingga Oktober 2018. Model evaluasi desain yang digunakan sebagai berikut.

Teknik analisis data yang digunakan dalam penelitian ini menggunakan analisis deskriptif melalui model Miles dan Huberman yang terdiri dari tiga tahap seperti, reduksi data, display data, dan verifikasi. Tahap verifikasi adalah langkah terakhir yang berisi rekomendasi bagi pemangku kepentingan untuk memutuskan kebijakan berdasarkan data dalam penelitian ini. Peserta penelitian ini terdiri dari seluruh pemangku kepentingan TK Negeri 1 Pembina Samarinda antara lain guru, siswa, orang tua murid perizinan dan pemangku kepentingan sekolah dasar.

\section{HASIL DAN PEMBAHASAN}

Evaluasi dalam penelitian ini berfokus pada implementasi Pendidikan Anak Usia Dini dalam berbagai studi literatur, standarisasi Program Pendidikan Anak Usia Dini Terpadu dalam Peraturan Pendidikan Nasional Nomor 58 Tahun 2009, Permendikbud Nomor 137 dan 146
Tahun 2014 yang diselenggarakan oleh TK Negeri 1 Pembina Samarinda. Sebagai hasil dari penelitian ini, dapat diketahui bahwa beberapa aspek dalam pelaksanaan Program Anak Usia Dini Terintegrasi, di TK Negeri 1 Pembina Samarinda menunjukkan hasil yang baik. Hasil evaluasi dalam penelitian ini akan disajikan dalam beberapa poin sesuai dengan model evaluasi yang digunakan adalah CIPPO yang meliputi komponen konteks, input, proses, produk, dan hasil. Aspek yang akan dievaluasi adalah sebagai berikut; dalam komponen konteks, yang mencakup dasar formal untuk pelaksanaan Sekolah Anak Usia Dini Terpadu di TK Negeri 1 Pembina mendeskripsikan sejauh mana adanya penyelenggaraan yang mendapat dukungan orang tua serta masyarakat terhadap lembaga dan perspektif pengelola tentang implementasi program PAUD Terpadu. Temuan di lapangan menunjukkan bahwa selama ini TK Negeri 1 Pembina telah di dukung oleh orang tua/wali murid melalui pembentukkan Komite Sekolah. Komite Sekolah berfungsi sebagai mitra program penyelenggaraan pendidikan di TK Negeri 1 Pembina Samarinda. Keberadaan Komite Sekolah melalui hasi penelitian oleh penulis di ketahui bahwa dibentuk berdasarkan asesmen kebutuhan sekolah. Pihak sekolah melalui Komite sering melakukan koordinasi terkait program - program unggulan dan layanan PAUD yang dibutuhkan oleh seluruh orang tua/wali murid. Adapun mekanisme pemilihan 
pengurus Komite Sekolah di bentuk melalui rapat bersama seluruh dewan pengurus sekolah. Selain hal tersebut, dukungan masyarakat sekitar pun memberikan keterlibatan yang sangat baik. Hal tersebut terwujud melalui dengan antusias kepercayaan masyarakat dalam berpartisipasi menyekolah anak - anak ke TK Negeri 11 Pembina Samarinda.Masyarakat pub berpartisipasi sebagai narasumber mitra bagi lembaga serta menjadi peserta pelatihan pembelajaran PAUD berbasis pendekatan kurikulum 2013. Berdasarkan data peserta yang di miliki oleh penyelenggara, sebagian dari berbagai daerah se-Kalimantan Timur untuk mengikuti program magang, bahkan juga terdapat data dari mahasiswa luar negeri yang pernah magang di TK Negeri 1 Pembina Samarinda. Adapun mengenai deksripsi pengelola, sejauh ini pelaksanaan program PAUD Terpadu bersinergi melalui pemerintahan yang di wakili oleh Dinas Pendidikan Tingkat Kota Samarinda., Ketua Program Studi PGPAUD Universitas Mulawarman, Dinas Kesehatan serta komunitas - komunitas pendidikan anak usia dini seperti pecinta anak berkebutuhan khusus serta drumb band. Dengan adanya sinergi tersebut, berdampak pada kemajuan layanan pendidikan anak usia dini di TK Negeri 1 Pembina Samarinda.

Komponen input, termasuk manajemen siswa yang berkaitan dengan pengelompokan usia, manajemen guru, ketersediaan fasilitas dan infrastruktur, manajemen pembiayaan dan perencanaan program pembelajaran di TK Negeri 1 Pembina. Hasil penelitian menunjukkan bahwa pengelolaan siswa telah sesuai standar yang mencakup usia, zona wilayah tempat tinggal, serta mendata biodata diri secara holistik pada siswa. Sementara, berkenaan pada pengelolaan guru kebanyakan adalah guru honor yang direkrut dari peserta magang yang ingin mengabdikan diri sebagai bagian dari TK Negeri 1 Samarinda ditempatkan berdasarkan klasifikasi usia siswa. Hingga akhir tahun 2017, a TK Negeri 1 Pembina berubah menjadi PAUD Negeri 1 Samarinda. Adapun aspek ketersedian fasilitas dan sarana prasarana selama ini di tunjang oleh keberadaan Komite Sekolah, bantuan dari pemerintah baik tingkat Kota hingga Pusat yang di kelola untuk penambahan sarana prasarana seperti aula pertemuan, fasilitas UKS serta renovasi kelas dengan penambahan media pembelajaran bagi anak usia dini.

Dalam komponen proses meliputi aspek implementasi dan penilaian program pembelajaran di TK Negeri 1 Pembina Samarinda. Ini menggambarkan penilaian dan evaluasi profesional di kelas oleh guru. Hasil penelitian di lapangan menunjukkan bahwa proses pembelajaran menggunakan pengembangan kurikulum 2013 yang terbagi pada layanan usia lahir hingga 6 tahun. Program pembelajaran di modifikasi melalui tim pengembang kurikulum yang berbasis pendekatan local wisdom (kearifan 
lokal) kota Samarinda. Sebagai contoh seperti jenis-jenis buah yang tumbuh di Samarinda dan mengembangkan kreasi gerak dan lagu tema binatang khas seperti Ikan Pesut. Pelaksanaan pembelajaran pun mengakomodasi kebutuhan minat bakat anak. Salah satu program tersebut adalah ekskul drumb band di TK Negeri Pembina 1 Samarinda. Mengenai penilaian pembelajaran yang dilakukan oleh guru melalui pendekatan saintifik serta berbasis tumbuh kembang anak. Keseluruhan teknik penilaian dan prosedur penilaian pembelajaran telah menunjukkan sangat sesuai dengan batasan penilaian di dalam kurikulum 2013. Akan tetapi, pada aspek penilaian terdapat beberapa anak inklusif yang membutuhkan bantuan mitra lain dalam melakukan asemen. Mitra tersebut seperti psikolog maupun dokter anak. Hal tersebut mengacu pada petunjuk teknis program PAUD Holistik Integratif.

Komponen produk selanjutnya memuat aspek tentang deksripsi hasil pembelajaran berupa tingkat pencapaian perkembangan dan kesiapan anak memasuki pendidikan lanjutan di Sekolah Dasar.

Pada aspek tersebut dapat di pahami bahwa ketercapaian tingkat pencapaian perkembangan siswa menunjukkan kesesuaian terhadap batasan kompetensi dasar di dalam Kurikulum 2013 yakni bidang perkembangan agama-moral, bahasa, sosial-emosional, kognitif, fisikmotorik dan seni. Hal tersebut dapat diketahui melalui dokumen laporan pencapaian perkembangan siswa dan hasil raport di TK Negeri 1 Pembina Samarinda yang dilaporkan pada setiap minggu, bulan, dan akhir semester kepada orang tua/wali murid.

Melalui dokumen tersebut, guru mengkomunikasikan segala pencapaian siswa beserta bukti-bukti berupa karya/prakarya dan hambatan - hambatan kesulitan belajar yang siswa alami di kelas selama pembelajaran. Dokumen laporan pencapaian perkembangan serta raport siswa juga memuat kegiatan - kegiatan tambahan yang siswa ikuti, sebagai contoh ekskul drumband di TK Negeri 1 Pembina Samarinda. Dengan kata lain, segala informasi mengenai siswa dapat diperoleh orang tua / wali siswa melalui dokumen laporan pencapaian perkembangan dan raport akhir semester.

Dalam komponen outcomes berisi tentang persepsi pemangku kepentingan di SD terhadap lulusan TK Negeri 1 Pembina terkait dengan aspek - aspek kemampuan akademik dan kemampuan non akademik.

Hasil penelitian yang diperoleh terhadap aspek akademik, dari wawancara kepada Kepala Sekolah dan Wali Kelas 1 di beberapa sekolah dasar di Samarinda menunjukkan bahwa lulusan dari TK Negeri 1 Pembina memiliki kemampuan akademik yang sangat baik seperti kemampuan membaca dan menghitung permulaan. Apresiasi dari lulusan tersebut menjadi ajang promosi dari TK Negeri 1 
Pembina Samarinda dalam mendapatkan calon-calon siswa yang ingin bersekolah.

Pada aspek non-akademik, di ketahui bahwa lulusan dari TK Negeri 1 Pembina Samarinda menunjukkan sikap kemandirian yang sangat baik, minat belajar tinggi dan kemampuan bersosialisasi terhadap teman sebaya dengan baik di dalam kelas. Sehingga sebagian lulusan siswa dari TK Negeri 1 Pembina Samarinda dari persepsi pengguna lulusan sangat baik dan di beberapa SD tertentu, lulusan tersebut dapat berprestasi serta berkompetisi dengan lulusan lain.

Dengan demikian, dapat di pahami bahwa hasil keseluruhan terhadap aspek aspek dalam evaluasi program pendidikan PAUD Terpadu di TK Negeri 1 Pembina Samarinda telah menunjukkan hasil yang sangat baik di tinjau dalam berbagai perspektif penyelenggaraan secara terpadu. Akan tetapi, rekomendasi yang perlu di pertinbangkan oleh pemangku kebijakan di TK Negeri 1 Samarinda adalah memiliki sekolah - sekolah PAUD yang menjadi lembaga binaan pelaksanaan penyelenggaraan PAUD berbasis kurikulum 2013. Mengingat kedudukan TK Negeri 1 Pembina Samarinda ialah school project dari pihak Dinas Pendidikan Kota Samarinda berkaitan implementasi kurikulum 2013.

\section{PENUTUP}

\section{Kesimpulan}

Hasil penelitian ini adalah berupa rekomendasi kebijakan - kebijakan untuk pemetaan lembaga pendidikan anak usia dini oleh TK Negeri 1 Pembina sebagai program pembinaan penyelenggaraan kurikulum 2013 yang akan membantu pencapaian peningkatan kemajuan kualitas layanan pendidikan anak usia dini di Kalimantan Timur.

\section{Saran}

Adapun yang dapat menjadi rekomendasi kebijakan adalah perlunya melakukan pemetaan untuk PAUD-PAUD baru yang dapat menjadi program lembagai PAUD binaan untuk implementasi dan program kurikulum berjalan sesuai standar yang ditetapkan oleh Pemerintah yaitu kurikulum 2013.

\section{DAFTAR PUSTAKA}

Arikunto, Suharsimi. (2010). Prosedur Penelitian. Jakarta:Rineka Cipta.[1]

Arikunto, Suharsimi dan Cepi Safrudin Abdul Jabar. (2014). Evaluasi Program Pendidikan. Jakarta: Bumi Aksara.[2]

Beaty, Janice J. (2013). Observasi Perkembangan Anak Usia Dini. Jakarta: Kencana.[3]

Biddle, Kimberley Gordin, et.al. (2014). Early Childhood Education Becoming Professional. California:SAGE Publication.[4]

Catron, Carol. E. dan Jan Allen. (1999). Early Childhood Curriculum. United State: Prentice Hall, h.58-59.[5] 
Click, Phylis and Kimberly A. Kankos. (2008). Administration of Program for Young Children. New York: Thomson Delmar Learning.[6]

Creswell, John. W. (2009). Research Design Qualitative, Quantitative, and Mixed Methods Approaches Third Edition. California: SAGE Publication.[7]

Danim, Sudarwan. (2010). Perkembangan Peserta Didik. Bandung: Alfabeta. [8]

Djaali dan Pudji Muljono. (2008). Pengukuran dalam Bidang Pendidikan. Jakarta:Penerbit Grasindo.[9]

Essa, Eva. L. (2011). Introduction Early Childhood Education, Sixth Edition. Wadsworth:Cengage Learning.[10]

Frankel, Norman E. Wallen, dan Helen H. Hyun. (2012). How to Design and Evaluate Research in Education. Eight Edition. New York:McGraw-Hill.[11]

Ghony, M. Djunaidi dan Fauzan Almanshur, (2012). Metodologi Penelitian Kualitatif. Jogjakarta:AR-Ruzmedia.[12]

Gullo, Dominic. F. (2005). Understanding Assesment and Evaluation in Early Childhood Education. New York: Teacher College Press.[13]

Jackman, Hilda L, (2009). Early Education Curriculum, fourth edition. Belmont: Delmar.[14]

Jackman, Hilda L. (2012). Early Education Curriculum: A Childs's Connection To The World Fifth Edition. Cengage Learning Products Are Represented In Canada by Nelson Education, Ltd.[15]

Kirkpatrick. (2008). Evaluating Training Program Third Edition(New York : BerretKoehler Publisher, Inc.[16]

Syamsuddin, S. and Jafar, F.S. (2015). Pengharapan Orangtua Terhadap Anak PraSekolah Ditinjau Dari Psikologi Perkembangan Anak. Edusentris, 2(1), pp.88-97.[17]
Santoso, Soegeng. (2011). Konsep Pendidikan Anak Usia Dini Menurut Pendirinya 1. Jakarta:Tanpa Penerbit,.[18]

Sudjana, Djudju. (2008). Evaluasi Program Pendidikan Luar Sekolah. Bandung:Rosda Karya.[19]

Sugiyono. (2010). Metode Penelitian Pendidikan,Bandung:Alfabeta.[20]

Tayibnapis, Farida. Yusuf. (2008). Evaluasi Program dan Instrumen Evaluasi untuk Program Pendidikan dan Penelitian. Jakarta: Rineka Cipta.[21]

Tedjawati, dkk. (2010). Laporan Penelitian Program Insentif Peningkatan Kemampuan Peneliti dan Rekayasa : Pengembangan Model PAUD Percontohan. Jakarta:Pusat Penelitian dan Inovasi Pendidikan.[22]

Wirawan. (2012). Evaluasi: Teori, Model, Standar, Aplikasi dan Profesi. Jakarta: Rajawali Press.[23] 